enormous dangers, coupled with a guarded optimism that, with their recognition, the worst could be avoided - Gabor pursued and developed in a series of further publications. He became a founder member of the Club of Rome, and thereby became embroiled in the fierce debates which followed the publication of Limits to Growth by Forrester and Meadows. His stance was one of cheerful and total support for these authors - though a careful examination of his expressed opinions reveals that this support did not, in fact, rest on his assessment of the computer model calculations which caused such widespread alarm.

Just before Inventing the Future, it became clear that holography, transformed by the discovery of the laser, was turning into one of the most rapid

\section{Airey Neave}

A General Election is a deep parliamentary gulf dividing sharply one time from another. I have returned to the House of Commons not only to a new parliament and a new government but to unfamiliar faces that crowd the benches as solidly and confidently as did those whose places they have taken. But there is outstandingly one face absent from the chamber, one expected figure not again to be met in the long corridors. I refer to my friend Airey Neave, the victim of a cowardly political murder within the precincts of that same Palace of Westminster where we meet.

Leading figures in public life, the newspapers, radio and television have all said so much deservedly in tribute to $\mathrm{Mr}$ Neave, his life and work, that it might seem presumption on my part to add more. Nevertheless these columns give me an opportunity to enlarge a little on his considerable services to the Select Committee on Science and Technology of the House of Commons, for Airey Neave was a founder member of the committee from its establishment in 1967 until 1975 when he became opposition spokesman on Northern Ireland.

I was the first chairman of the select committee but in 1970 when the Conservative government of $\mathrm{Mr}$ Heath came to power, in accord with parliamentary practice, Airey Neave succeeded me for the parliamentary sessions of 1970-1974. Every chairman, I suppose, has his own style and Airey's was very much his own. In dealing with witnesses, especially those (and there are a few) who think that politicians cannot possibly have knowledge of anything except the suspect business of getting elected, he could be severe to near inquisitorial. Yet never for an instant did he go beyond the needs of the inquiry being conducted. As a good select committee chairman should, he saw his primary duty to parliament, not to governments or parties. I remember well how he gave a rising Conservative ministerial star caught out in a mistake a wigging that led to with- growth topics in applied science. The range of applications appeared to grow month by month; holography was recognised as a principle of such generality tht it could touch many branches of physics, biology and engineering. Gabor, himself, contributed several inventions to this growing field. He lectured widely on the subject. Many will never forget a brilliant discourse at the Royal Institution which he gave in 1969 . The recognition, so long denied, or belatedly bestowed, came in full flood. Honours of all kinds were showered upon him and, in 1972, the Nobel Prize.

There remained some good years. They were devoted to scientific work at the CBS Laboratories in the USA, to Imperial College and London, and to a villa in Italy. Gabor continued to contribute to what became his dominant and passionate

drawal and public apology. But to the general run of helpful and co-operative witnesses, enduring the unfamiliar ordeal of questioning in public, Airey was the soul of courtesy.

In the chair Airey Neave was vastly impressive to witnesses as he was to colleagues on the committee because of his detailed knowledge of the subject under consideration. His capacity for work was truly prodigious. Among the inquiries he handled either as chairman of the main committee or as chairman of a subcommittee, were population control, the Rothschild proposals and the computer industry.

But I suppose the inquiry that brings me closest to Airey Neave in memory was the one that the select committee carried out, through a sub-committee, into the choice to be made by Britain for the 'third generation' of nuclear reactors, the Magnox reactor being counted first generation and the advanced gas-cooled reactor second generation. This was during the time of the Heath government, when $\mathrm{Mr}$ Peter Walker was, as Secretary of State for Technology, the responsible minister.

The assumption had been that no firm decision would be taken on the choice to be made without a ministerial statement and the normal opportunity for parliamentary questioning. Then a long special article appeared in a leading Sunday newspaper by a science correspondent, to the effect that the Central Electricity Generating Board had made up its mind already and that American style pressurised water reactors were to be bought on a large scale for installation in the British electricity supply system, with the co-operation of our manufacturers and the apparent approval of the government.

Simple parliamentary questioning took us little further forward and Airey and I both agreed that this was just the kind of situation for which the select committee had been established.. After all, the British taxpayer had either spent or had guaranteed large sums of money in the past on the assumption that Britain had the most efficient and safest nuclear power arrange- concern - the adjustment of the human condition to the new world, which the explosive development in science and technology had wrought within his own lifetime and experience. Prophecy is the hardest of arts; scientists as a body are not notably more successful than others in its practice. Yet, if any doubt that there are some, a very few, who can penetrate that ultimate unknown at least some little distance, they should re-read Inventing the Future of 1963, or, perhaps, the Fawley Lecture of 1972, The proper priorities of Science and Technology.

Dennis Gabor married Marjorie, née Butler, in 1936, a marriage which brought great happiness and continuing support, in a life which knew both bitter disappointment as well as triumph and total fulfilment.

Eric A. Ash

ments in the world with the gas-cooled systems and now for parliament to be told that we had been wrong all the time took more than a little swallowing.

Because of his declared interest as a director of a plant manufacturer engaged in the nuclear field, Airey Neave felt he should not take the chairmanship of the inquiry and I occupied his place, though he served on the sub-committee. To a great extent it was the safety of the PWR in an emergency situation that took the attention of the inquiry and on this point critical evidence was received from Sir Alan Cottrell, then Chief Scientist to the government - evidence which had not been published before.

The conclusion of the select committee, reported to the House of Commons, was that the case for abandoning British reactor systems and adopting the American system could not be sustained by the evidence submitted and we advised caution over the PWR. Needless to say, some but not all parts of the nuclear technological establishment attacked the select committee for political meddling and worse. Nevertheless, a full day's debate in the Commons found members of parliament on both sides impressed by the committee's findings and Airey and I followed up the debate with a joint appearance on the national television network which engendered a large correspondence. Many of our correspondents were obviously impressed by the way in which a select committee of the Commons could, while supporting nuclear development in general, run up a danger flag about one particular proposed development. Who in the light of Harrisburg could to-day say we were wrong?

I spoke to Airey Neave last on the Thursday night before his death on the following day. We met by chance in the Commons lobby and discussed the future of the selectl committee on Science and Technology in the light of suggested procedural reforms for select committees in a new parliament. I did not know then I was never to see him again.

Arthur Palmer 